\title{
RIZIKOS VEIKSNIŲ POVEIKIS ODOS IR AUDINIŲ VIENTISUMUI
}

\author{
Zita Gierasimovič ${ }^{1,2}$, Zyta Kuzborska ${ }^{3}$, Jelena Kutkauskiené ${ }^{4}$ \\ ${ }^{1}$ Vilniaus universiteto Medicinos fakulteto Sveikatos mokslu institutas, \\ ${ }^{2}$ Vilniaus universiteto ligonine Santaros klinikos, \\ ${ }^{3}$ Vilniaus Gedimino technikos universitetas, \\ ${ }^{4}$ Mykolo Romerio universiteto Teisès mokyklos Viešosios teisès institutas
}

Raktažodžiai: slègio opų priežiūra, rizikos veiksniai, prevencinès priemonès.

\begin{abstract}
Santrauka
Darbo tikslas. Išanalizuoti veiksnius, darančius įtaką slègio opų išsivystymui.

Tyrimo medžiaga ir metodai. Tyrimas vyko vienoje Vilniaus miesto universiteto ligoninejje. Slègio opu atsiradimo rizikos vertinimui naudota modifikuota Nortono skalè. Analizuoti 655 pacientų slègio opu atsiradimo atvejai. Statistinè duomenų analizè atlikta naudojant IBM SPSS Statistics 19,0 ir Microsoft Office Excel 2016 programas. Taikyti aprašomosios statistikos metodai. Ryšio stiprumo laipsnis ịvertintas apskaičiuojant šansų santykị OR ir jo atitinkamą pasikliautinaji intervalą (PI $95 \%$ ). Statistinio patikimumo rodiklis vertintas, kai $\mathrm{p}$ reikšmé ne didesnè kaip $0,05(\mathrm{p} \leq 0,05)$, ir daroma išvada, kad skirtumai yra statistiškai reikšmingi.

Darbo rezultatai ir išvados. Mažiau nei pusè pacientu (41,5 proc.), dažniau 55-74 metų, atvykimo gydytis metu turejo slègio opų. Odos ir audinių vientisumo pažeidimų daugiau nei pusę atvejų $(83,4$ proc.) pastebejjo ir ịvertino slaugos personalas, dažniau pacientams iki 80 metų, atvykusiems planine tvarka. Labai didelę tikimybę atsirasti slègio opoms turèjo atvykusieji skubos tvarka, kurių odos būklè ịvertinta 6-10 taškų (2,6 proc.). Ketvirtadalio ( 25,0 proc.) atvykusiųu planine tvarka odos būklè buvo įvertinta 5 taškais. Moterys ir vyrai turi vienodas slègio opu išsivystymo galimybes $(p=0,001)$. Odos ir audinių vientisumo pažeidimo rizikos veiksniai: šlapinimosi problemos (69,6 proc.), psichologinè būklè (13,4 proc.), odos būklè (4,9 proc.). Atvykimo metu ir odos pažeidimų gydymo stacionare laikotarpiu, II stadijos slègio opų dažnis buvo vienodas (55,6 proc.).
\end{abstract}

Daugiau nei pusès pacientų ( 60,0 proc.) slègio opos vieta buvo nugaros srityje, rečiau - kūno šonuose $(1,2$ proc.) ir pilvo srityje $(1,7$ proc.) $(\mathrm{p}=0,0001)$. Besigydantiems ir turintiems slègio opų pacientams $(41,8$ proc.) taikytos profilaktinès ir slaugos pagalbinès priemonès. Tiriamiesiems, kurių odos būklè ịvertinta mažiau nei 14 taškų ir turintiems slègio opų, taikytos profilaktinès ir slaugos pagalbinès priemonès slègio opų prevencijai.

\section{İvadas}

Odos, audinių vientisumo pažeidimas - tai ịvairaus laipsnio pragulos (lot. decubitus), atsiradusios dèl uždegiminio proceso, nekrozès, dar vadinamos slègio opomis (pressure sores) [1]. Išoriniai ir vidiniai rizikos veiksniai, darantys ittaką îvairių laipsnių audinių pažeidimui, dažni žmonèms, kuriems dèl riboto savarankiškumo bei judejjimo, sutrikdyta audinių mityba [1]. Rizikos veiksnių (drègmès, spaudimo) poveikis ị kūno paviršiaus odą predisponuoja slègio opu atsiradimą, todèl ilgejja gydymo laikas ir didejja išlaidos. Slègio opų atsiradimo rizikos vertinimo Nortono skalè leidžia predisponuoti audinių pažeidimus. Išsamus slègio opos atsiradimo ịvertinimas yra pagrindinè ir tinkama naujų odos pažeidimų prevencijos priemonè, efektyvi teikiant individualizuotą opos priežiūrą.

Išoriniai ir vidiniai rizikos veiksniai daro įtaką odos, audinių vientisumo pažeidimui, lètina gydymo laikotarpi, sunkina slėgio opos priežiūrą, mažina pacientų savarankiškumą. Rizikos veiksniai, prasta mityba, ilgalaikis kūno paviršiaus odos spaudimas predisponuoja odos ir audiniu pažeidimų atsiradimą $[1,2]$. Slègio opos dažniau išsivysto senyviems pacientams, vyresniems nei 70 metų, arba tiems, kurių judejimas apribotas. Esant neurologinių reiškinių, kartais (5-8 proc.) pragulos tampa mirties priežastimi $[2,3]$. Paciento priverstinè padètis provokuoja kraujotakos sutrikimus, atsiranda edemos, sumažèja pažeistų odos sričių jutimas. 
Vienas iš etiologinių rizikos veiksnių yra odos maceracija, o drègmè, prakaitas, slègio atsiradimas audiniuose, išmatos ir šlapimo nelaikymas spartina odos audinių pažeidimus [3]. Ankstyvieji odos pažeidimų požymiai: neịprasti odos tekstūros ar spalvos pokyčiai, patinimas, pažeistos odos plotai yra vėsesni ar šiltesni nei kitos kūno sritys [4]. Pirmieji rizikos požymiai: pažeidimų vietoje oda yra šiltesnè, gali niežèti, ilgainiui parausta, atsiranda pūslelè su skysčiu, kuri trūkusi primena kraterio paviršių. Infekcijos požymiai yra karščiavimas, nemalonus odos kvapas (provokuoja drégmè iš opų), padidejjusi odos paraudimo, patinimo sritis. Odos ir audinių pažeidimo laipsnis svyruoja nuo raudonos, nepažeistos odos iki giliojo pažeidimo, apimančio audinius, raumenis ir kaulą [5]. Slégio opos vystosi keturiais etapais. Nustačius jas ankstyvoje stadijoje, galima gydyti ir sumažinti komplikacijų riziką. Norint išvengti slègio opos, labai svarbu pacientams dažnai judèti, o statinè kūno poza provokuoja slėginius sėdmenų, pečių lanko, stuburo, rankų ir kojų srities pažeidimus. Mažinant rizikos veiksnių poveikị, keičiama kūno padètis ir mažinamas slègis. Slègio opų priežiūrai svarbios prevencinès priemonès, kurios daugiau nei penkis kartus sumažina slègio opos išsivystymo riziką [6]. Opų rizikos prevencija svarbi nutukusiems žmonėms, nes jiems nuo trinties (patalynè, ankštų drabužiu sagos) slèginès opos gali atsirasti bet kuriose kūno vietose, dažniausiai tose, kurios daugiausiai liečiasi su plokštuma, ant kurios pacientas guli $[6,7]$. Prevencinių priemonių veiksmingumas gydant slègio opas buvo pastebètas atlikus klinikinius eksperimentus. Slègio opos suformuotos žaizdos, audinių pažeidimai užgyja maždaug per 6 savaites. Pateiktos priežiūros rekomendacijos, kaip išvengti slėgio opų, ne visuomet garantuoja greitą gydymo rezultatą [7]. Mokslinès literatūros šaltiniuose $[8,9]$ teigiama, kad klaidingi slaugos personalo veiksmai skatina slėgio opų vystymąsi: blogai parengtas slėgio opu stebejjimo planas, ribotos ar netinkamai pritaikytos slègio opų prevencijos priemonès ir trūkumas žinių, personalo užmaršumas. Nors mokslinejje literatūroje pateikiama daugybè būdų, kaip išspręsti slègio opų išsivystymo problemas [9], o kartu ir brangaus jų gydymo, kai kurių pažeidimų išgydyti nepavyksta - tai viena iš sudètingiausių užduočių, slaugant nejudrius pacientus.

Tarptautineje pragulų klasifikavimo sistemoje (angl. International NPUAP-EPUAP Pressure ulcer classification system) yra kelios slègio opų stadijos. Europos šalyse, remiantis vienkartiniais tyrimais, I-IV stadijos slègio opų išsivystymo rizika įvairiose amžiaus grupèse siekia 18,1 proc. [2]. Nugara ir kulnai yra dažniausiai paveiktos odos vietos $[3,4]$, Kanadoje jos sudaro nuo 15,8 proc. iki 28,2 proc. [5]. Slègio opu paplitimas Lietuvoje svyruoja nuo 2,7 proc. iki 29,5 proc. visų hospitalizuotų pacientų [6]. Prevencinès priemonès predisponuoja kūno audinių pažeidimus bei pagreitina žaizdų gijimą [7].

Tyrimo tikslas - išanalizuoti veiksnius, darančius įtaką slègio opų išsivystymui.

\section{Tyrimo medžiaga ir metodai}

Trejų metų tyrimas vyko vienoje Vilniaus miesto universiteto ligoninèje. Odos, audinių pažeidimai vertinti 655 pacientams, naudojant klinikinių rodiklių modifikuotą Nortono skalès protokolą, kuriame kiekvienas iš penkių parametrų (fizinè, psichinè pacientų būklè, tuštinimosi, šlapinimosi problemos, aktyvumas, mobilumas) vertinti taškais nuo 1 - „labai blogai“, iki 5 - „labai gerai.“ Slégio opų atsiradimo galimybè vertinta taškais nuo 1 iki 20, bendros rizikos rezultatas, mažesnis nei 14 taškų, vertintas kaip slègio opos grèsmè, kuriai reikia taikyti prevencines priemones. Kuo didesnis surinktų taškų skaičius, tuo mažesnè slègio opų atsiradimo rizika. Protokole buvo nurodomi duomenys apie tiriamuosius (amžius, lytis, atvykimo būdas, gydymosi ligoninèje laikotarpis, odos būklè).

Statistiné duomenų analizė atlikta naudojant IBM SPSS Statistics 19,0 ir Microsoft Office Excel 2016 programas. Taikyti aprašomosios statistikos metodai. Apskaičiuotos imčių charakteristikos: absoliutus skaičius (n), procentas (proc.). Ryšio stiprumo laipsnis buvo įvertintas apskaičiuojant šansų santykị OR ir jo atitinkamą pasikliautinaji intervalą (PI $95 \%$ ). Skirtumai tarp rizikos veiksnių buvo vertinami naudojant Pearson chi kvadrato kriterijų $\left(\chi^{2}\right)$. Statistinio patikimumo rodiklis vertintas, kai p reikšmė ne didesnè kaip $0,05(\mathrm{p} \leq 0,05)$, ir daroma išvada, kad skirtumai yra statistiškai reikšmingi.

Tyrimo metu vertinti 655 tiriamujų protokolų duomenys. Vidutinis pacientų amžius - 61,7 metai. 423 (64,6 proc.) tiriamieji atvyko ị stacionarą, turèdami slègio opų (mažiausias slègio opų skaičius - 1). 232 (35,4 proc.) tiriamiesiems slėgio opos atsivėre gydantis stacionare vidutiniškai per 9,5 dienas. Skubos tvarka atvykusiems tiriamiesiems (13,1 proc.) odos būklè nebuvo vertinta, vertinimas atliktas gydymosi laikotarpiu.

\section{Rezultatai}

Odos ir audinių pokyčiai nustatyti atvykusiems 386 (58,9 proc.) tiriamiesiems. Daugumai (41,5 proc.) 55-74 metų tiriamujų slégio opos nustatytos atvykimo metu. Odos pažeidimų beveik nebuvo (1,6 proc.) vyresnių kaip 81 metų amžiaus grupeje, tačiau 18 (4,7 proc.) šios grupès tiriamujų nustatyti audinių pažeidimai. Nepažeista, sveika odos būklè nustatyta iki 35 metų amžiaus grupejje (3,3 proc.). Didelè (39,4 proc.) slègio opų atsiradimo rizika yra 75-80 metų amžiaus grupėje. Atvykusiems gydytis 35-54 metų tiriamiesiems nustatytos 
slėgio opos (10,4 proc.). Odos ir audinių pažeidimų nustatyta ir iki 35 metų amžiaus grupeje ( 4,1 proc., $n=16)$, (1 lentelè).

Ir atvykimo metu, ir gydymosi stacionare laikotarpiu tiriamujų odos būklès pokyčius pastebejjo slaugos personalas (82,0 proc. atveju), gydytojai (15,9 proc. atvejų) ir skubiosios pagalbos darbuotojai (2,1 proc. atveju). Tikimybę slègio opu atsiradimui turejo atvykusieji planine tvarka (32,9 proc.), gydomi stacionare $(4,1$ proc.) ir atvykusieji skubos tvarka $(2,6$ proc.). Jų odos būklès ir audinių pažeidimo vertinimo taškų skaičius siekè nuo 6 iki 10. Sunkesnès būklès tiriamieji $(15,9$ proc.) turèjo didžiausią slègio opų išsivystymo tikimybę, jų odos ir audinių būklè įvertinta 1-4 taškais, dažniau (14,9 proc.) atvykusieji planine tvarka. Penkiais taškais įvertinti 26,3 proc. tiriamujų odos ir audinių pažeidimai (2 lentelè).

Skubos ir planine tvarka atvyko 423 (64,6 proc.) tiriamieji su slègio opomis. Pirmos apžiūros metu 215 vyrų nustatytos slègio opos. Iš jų 83 (38,6 proc.) atvyko skubos tvarka ir 132 (61,40 proc.) - planine tvarka. 208 atvejais slègio opos nustatytos moterims, iš jų 116 (55,8 proc.) atveju atvykusioms skubos tvarka ir 92 (44,2 proc.) atvejai - planine tvarka. Ir moterys, ir vyrai turi vienodas slégio opu išsivystymo galimybes ( $\mathrm{p}=0,001)$, (3 lentelè).

Vertintas rizikos veiksnių poveikis odos ir audinių vientisumui. 12,5 proc. tiriamujų turèjo odos, psichologinès būklès, aktyvumo stokos, šlapinimosi ir tuštinimosi problemų. Vienu balu dažniau (11 atvejų) buvo vertinta psichologinè būklè, tiriamieji vangiai bendravo, buvo neramūs. Didesnei tiriamujuc daliai $(63,4$ proc.) nustatytos šlapinimosi ir tuštinimosi problemos, odos būklès pokyčiai pažymèti 4,9 proc. tiriamujų. Odos būklè labai gera (2,6 proc., 5 balai), mobilūs (20,3 proc.), savarankiškai ir aktyviai juda (10,0 proc.). Dauguma (61,9 proc.) tiriamujų neturèjo šlapinimosi ir tuštinimosi problemų. Personalo padedami, judèjo riboto mobilumo tiriamieji (19,6 proc.), daugelis iš jų (69,6 proc.) turejo šlapinimosi ir tuštinimosi problemų. Blogas (2 balai) judejjimo aktyvumas, mobilumas bei šlapinimosi ir tuštinimosi problemos nustatytos 15,6 proc. tiriamujų. Gera keturių balų būklè nustatyta 23,8 proc. tiriamujju (4 lentelè).

Rekomenduotas kūno padèties keitimas (vartymas, skatinimas judèti, patogios kūno padèties parinkimas) ir taikytos antipragulinès priemonès 268 (40,9 proc.) tiriamiesiems. Dažniau naudotos priemonès odos būklei pagerinti esant odos, šlapinimosi ir tuštinimosi problemų ( 68,3 proc.). Dažnesnè asmens higiena ir patalynès keitimas nustatytas tiriamiesiems, turintiems $1-2$ rizikos balus ( 66,8 proc.).

Ūminis visų odos sluoksnių uždegimas, I stadijos slègio opa nustatyta ir atvykimo metu (20,1 proc.), ir gydymosi stacionare metu (41,8 proc.). Daugumai tiriamujų (55,6 proc.) pasireiške epidermos ir dermos pratrūkimas (II slègio opos stadija). Tiriamiesiems atvykimo metu (17,9 proc.) ir gydy- mosi stacionare laikotarpiu (2,2 proc.) nustatytas netolygus odos ir poodinio sluoksnių pažeidimas (III stadijos slėgio opos). Rečiau IV stadijos slègio opos nustatytos gydymosi laikotarpiu (0,4 proc.). Atvykimo metu nustatytas slègio opos

1 lentelė. Slėginių opų skaičius atvykimo metu pagal amžiaus grupes

\begin{tabular}{|c|c|c|c|}
\hline \multirow{2}{*}{$\begin{array}{l}\text { Amžiaus grupès, } \\
\text { metais } n=569\end{array}$} & \multicolumn{2}{|c|}{ Atvyko pacientų, n (\%) } & \multirow[b]{2}{*}{$\mathbf{p},\left(\chi^{2}\right)$} \\
\hline & \begin{tabular}{c|} 
su slėgio opa \\
$386(67,8)$
\end{tabular} & $\begin{array}{c}\text { be slègio opos } \\
183(32,2) \\
\end{array}$ & \\
\hline Iki 35 & $16(4,1)$ & $6(3,3)$ & \multirow{5}{*}{$\begin{array}{c}\mathrm{p}=0,001 \\
(19,19)\end{array}$} \\
\hline $35-54$ & $40(10,4)$ & $30(16,4)$ & \\
\hline $55-74$ & $160(41,5)$ & $99(54,1)$ & \\
\hline $75-80$ & $152(39,4)$ & $45(24,6)$ & \\
\hline$\geq 81$ & $18(4,7)$ & $3(1,6)$ & \\
\hline
\end{tabular}

2 lentelè. Pacientų odos būklès ir slègio opų atsiradimo tikimybès vertinimas, taškais

\begin{tabular}{|l|c|c|c|}
\hline $\begin{array}{l}\text { Odos būklės verti- } \\
\text { nimas } \\
\mathbf{n = 6 5 5}\end{array}$ & $\begin{array}{c}\text { Atvykusieji } \\
\text { skubos } \\
\text { tvarka, } \\
\mathbf{n}(\mathbf{\%})\end{array}$ & $\begin{array}{c}\text { Atvyku- } \\
\text { sieji pla- } \\
\text { nine } \\
\text { tvarka, } \\
\text { n (\%) }\end{array}$ & $\begin{array}{c}\text { Gydymo } \\
\text { stacionare } \\
\text { metu, } \\
\mathbf{n}(\mathbf{\%})\end{array}$ \\
\cline { 2 - 4 } & $33(5,0)$ & $581(88,7)$ & $41(6,3)$ \\
\hline Slaugos personalas & $26(4,0)$ & $486(84,9)$ & $25(3,9)$ \\
\hline Gydytojai & $6(0,9)$ & $83(14,5)$ & $15(2,3)$ \\
\hline $\begin{array}{l}\text { Skubiosios pagalbos } \\
\text { darbuotojai }\end{array}$ & $1(0,2)$ & $12(2,1)$ & $1(0,2)$ \\
\hline $\begin{array}{l}\text { Slègio opu atsiradimo } \\
\text { tikimybè, taškų skai- } \\
\text { čius }\end{array}$ & & & \\
\hline $1-4$ & $5(0,8)$ & $98(14,9)$ & $1(0,2)$ \\
\hline 5 & $2(0,3)$ & $164(25,0)$ & $6(0,9)$ \\
\hline $6-10$ & $18(2,6)$ & $215(32,9)$ & $27(4,1)$ \\
\hline $11-14$ & $3(0,5)$ & $64(9,8)$ & $4(0,6)$ \\
\hline $15-20$ & $5(0,8)$ & $40(6,1)$ & $3(0,5)$ \\
\hline
\end{tabular}

3 lentelè. Slègio opų skaičius (pagal lytị) atvykimo ir gydymosi stacionare metu

Pastaba: * - statistiškai patikimas skaičius $p \leq 0,05$

\begin{tabular}{|c|c|c|c|c|}
\hline $\begin{array}{l}\text { Lytis } \\
\mathrm{n}=655\end{array}$ & $\begin{array}{l}\text { Slègio opų } \\
\text { skaičius } \\
\text { atvykus } \\
423(64,6)\end{array}$ & $\begin{array}{l}\text { Slègio opu } \\
\text { skaičius } \\
\text { stacionare } \\
232(35,4) \\
\end{array}$ & $\begin{array}{c}\text { OR } \\
\text { [PI 95 \%] }\end{array}$ & $\mathbf{p},\left(\chi^{2}\right)$ \\
\hline Vyrai & $215(50,8)$ & $163(70,3)$ & $\begin{array}{c}0,44 \\
{[0,31-0,62]}\end{array}$ & $\begin{array}{l}0,001 *, \\
(23,18)\end{array}$ \\
\hline Moterys & $208(49,2)$ & $69(29,7)$ & $\begin{array}{c}2,29 \\
{[1,63-3,21]}\end{array}$ & $\begin{array}{l}0,001 *, \\
(23,18)\end{array}$ \\
\hline
\end{tabular}


penetravimas ị giluminę fasciją ir aplinkinių audinių gilu pažeidimą ( 6,4 proc.).

Ilgalaikis pacientu judejjimo apribojimas (18,3 proc.), mobilumo stoka (1-2 balai) yra viena iš daugelio slègio opų rizikos veiksnių. Daugumai $(60,0$ proc.) atvykimo metu slègio opų lokalizacija nustatyta nugaros srityje arba apatinèse galūnėse $(24,1$ proc.). Gydymosi laikotarpiu slègio opų vieta yra šonai $(0,4$ proc.) ir pilvo sritis (1,7 proc.). Didžiausia nustatyta odos ir audinių pažeidimų dalis $(65,5$ proc.) yra nugaros srityje. Galvos srityje (pakaušis, kakta, ausys,

4 lentelè. Rizikos veiksniai, turintys įtakos slègio opų atsiradimui

\begin{tabular}{|c|c|c|c|c|c|c|}
\hline \multirow[t]{2}{*}{$\begin{array}{l}R \text { i z i k o s } \\
\text { veiksniai } \\
n=655\end{array}$} & $\begin{array}{c}1 \text { balas } \\
\text { (l. blogai) }\end{array}$ & $\begin{array}{c}2 \text { balai } \\
\text { (blogai) }\end{array}$ & $\begin{array}{c}3 \text { balai } \\
\text { (patenkina- } \\
\text { mai) }\end{array}$ & $\begin{array}{l}4 \text { balai } \\
\text { (gerai) }\end{array}$ & $\begin{array}{c}5 \text { balai } \\
\text { (l. gerai) }\end{array}$ & \multirow[t]{2}{*}{$\mathbf{p},\left(\chi^{2}\right)$} \\
\hline & $82(12,5)$ & $102(15,6)$ & $84(12,8)$ & $156(23,8)$ & $231(35,3)$ & \\
\hline Odos būklè & $4(4,9)$ & 0 & 0 & $2(1,2)$ & $6(2,6)$ & \multirow{5}{*}{$\begin{array}{c}\mathrm{p}= \\
0,001 \\
(44,189)\end{array}$} \\
\hline $\begin{array}{l}\text { Psichologinè } \\
\text { būklè }\end{array}$ & $11(13,4)$ & $1(1,0)$ & 0 & $2(1,2)$ & $12(5,2)$ & \\
\hline $\begin{array}{l}\text { Judèjimas } \\
\text { (aktyvumas) }\end{array}$ & $7(8,5)$ & $10(9,8)$ & $9(11,8)$ & $19(11,6)$ & $23(10,0)$ & \\
\hline Mobilumas & $8(9,8)$ & $20(19,6)$ & $27(16,5)$ & $19(25,0)$ & $47(20,3)$ & \\
\hline $\begin{array}{l}\text { Šlapinima- } \\
\text { sis, tuština- } \\
\text { masis }\end{array}$ & $52(63,4)$ & $71(69,6)$ & $48(63,2)$ & $114(69,5)$ & $143(61,9)$ & \\
\hline
\end{tabular}

5 lentelè. Slègio opų atsiradimo stadijos ir lokalizacijos vietos

\begin{tabular}{|c|c|c|c|c|}
\hline $\begin{array}{l}\text { Slègio opos sta- } \\
\text { dija } \\
n=655\end{array}$ & $\begin{array}{c}\text { Slėgio opos sta- } \\
\text { dija atvykimo } \\
\text { metu } \\
423(64,6)\end{array}$ & $\begin{array}{l}\text { Slègio opos sta- } \\
\text { dija stacionare } \\
232(35,4)\end{array}$ & $\begin{array}{c}\text { OR } \\
\text { [PI } 95 \%]\end{array}$ & $\mathbf{p},\left(\chi^{2}\right)$ \\
\hline I stadija & $85(20,1)$ & $97(41,8)$ & $\begin{array}{c}2,86 \\
{[2,01-4,07]}\end{array}$ & $\begin{array}{c}\mathrm{p}=0,001, \\
(35,21)\end{array}$ \\
\hline II stadija & $235(55,6)$ & $129(55,6)$ & $\begin{array}{c}0,998 \\
{[0,72-1,38]}\end{array}$ & $\begin{array}{c}\mathrm{p}=0,001 \\
(0,991)\end{array}$ \\
\hline III stadija & $76(17,9)$ & $5(2,2)$ & $\begin{array}{c}9,94 \\
{[3,96-24,96]} \\
\end{array}$ & $\begin{array}{c}\mathrm{p}=0,001, \\
(34,57)\end{array}$ \\
\hline IV stadija & $27(6,4)$ & $1(0,4)$ & $\begin{array}{c}11,46 \\
{[1,53-85,98]} \\
\end{array}$ & $\begin{array}{c}\mathrm{p}=0,003, \\
(8,92)\end{array}$ \\
\hline \multicolumn{5}{|l|}{$\begin{array}{l}\text { Slègio opos lo- } \\
\text { kalizacijos vieta }\end{array}$} \\
\hline $\begin{array}{l}\text { Galvos sritis (pa- } \\
\text { kaušis) }\end{array}$ & $3(0,7)$ & $12(5,2)$ & $\begin{array}{c}7,64 \\
{[2.13-27.35]}\end{array}$ & $\begin{array}{c}p=0,001 \\
(13,34)\end{array}$ \\
\hline Nugaros sritis & $254(60,0)$ & $152(65,5)$ & $\begin{array}{c}0,79 \\
{[0,57-1,10]}\end{array}$ & $\begin{array}{c}\mathrm{p}=0,168 \\
(1,902)\end{array}$ \\
\hline Pilvo sritis & $38(9,0)$ & $4(1,7)$ & $\begin{array}{c}5,63 \\
{[1,98-15,97]}\end{array}$ & $\begin{array}{c}\mathrm{p}=0,0001, \\
(13,157)\end{array}$ \\
\hline Apatinès galūnès & $102(24,1)$ & $45(19,4)$ & $\begin{array}{c}1,32 \\
{[0,89-1,96]}\end{array}$ & $\begin{array}{c}\mathrm{p}=0,166 \\
(1,92)\end{array}$ \\
\hline $\begin{array}{l}\text { Viršutinès galū- } \\
\text { nės }\end{array}$ & $13(3,1)$ & $13(5,6)$ & $\begin{array}{c}0,53 \\
{[0,24-1,17]}\end{array}$ & $\begin{array}{c}\mathrm{p}=0,113, \\
(2,52)\end{array}$ \\
\hline Šonai & $5(1,2)$ & $1(0,4)$ & $\begin{array}{c}2,76 \\
{[0,32-23,75]}\end{array}$ & $\begin{array}{c}\mathrm{p}=0,335 \\
(0,931)\end{array}$ \\
\hline
\end{tabular}

smakras) slėgio opų lokalizacijos vieta dažniau nustatyta gydymosi laikotarpiu (5,2 proc.), negu atvykimo metu $(\mathrm{p}=0,001)$. Apatinių galūnių pažeidimai 24,1 proc. dažniau nustatyti atvykimo metu, nei gydymosi laikotarpiu (19,4 proc.) (5 lentelè).

\section{Aptarimas}

Tyrimu siekta ịvertinti veiksnius, darančius įtaką slègio opų atsiradimui. Analizuojant gautus atsakymus matyti, kad didesnè dalis vyresnių nei 55 metų tiriamųų atvykimo ị stacionarą metu turejjo odos pažeidimų. Šios amžiaus grupès tiriamieji gydymosi stacionare laikotarpiu taip pat turèjo slègio opų. Panašūs ir kitų tyrejjų atliktų tyrimų duomenys. Vertinant amžiaus ịtaką slègio opų atsiradimui, dažniau nurodoma 70 metų ir daugiau $[8,2]$. Daugiau nei pusę slègio opų atvejų pastebejo slaugos personalas ir taikè antipragulines priemones, kūno padèties keitimą kaip prevencinius veiksmus ir priemones išvengti tolesnių odos pažeidimų. Slaugos personalas yra pagrindinè slègio opu prevencijos grandis, vertinanti ir taikanti prevencines priemones. Mūsų tyrime ir vyrų, ir moterų slègio opų išsivystymo galimybès buvo vienodos, nors atvykimo metu vyrams (5,6 proc.) odos pažeidimai pastebèti dažniau. Neaptikta kitų autorių tyrimų, kuriuose būtų nagrinèti atvykusių pacientų srautai ir komandos narių dalyvavimas slègio opų vertinime. Mūsų atliktame tyrime 28,0 proc. tiriamujjų turèjo šlapinimosi ir tuštinimuosi problemų ir judejjimo apribojimą, vertintą 1-2 balais. Daugiau nei pusei tiriamųjų dėl rizikos veiksnių poveikio taikytos priemonès - dažnesnis patalynès keitimas ir intensyvesnè asmens higiena. Šių rizikos veiksnių poveikị patvirtina ir daugelio autorių atlikti tyrimo duomenys, kad slègio opas provokuoja ir spartina odos maceracija, drègmè, šlapimo nelaikymas $[9,3]$. Slègio opu gydymas yra ilgalaikis procesas ir ne visuomet ga- 
rantuoja jų greitą gijimą. Mūsų tyrime nagrinèti slègio opų gijimo pokyčiai stebimi vidutiniškai po 9,5 dienų nuo jų nustatymo. Daugiau nei pusei tiriamujų pasireiškè epidermos ir dermos pratrūkimas su vienu audinių pažeidimo atveju. Daugiau nei pusei tiriamujų, nepriklausomai nuo atvykimo laiko, nustatyti ilgalaikiai odos ir audinių pažeidimai nugaros srityje, ketvirčiui - dažni apatinių galūnių odos pažeidimai. Šias išvadas patvirtina ir literatūra, kurioje aprašomos tos pačios slègio opų lokalizacijos vietos, kaip ir šiame tyrime $[10,11]$. Kiti tyrejai atskleidè, kad slègio opos užgyja maždaug šešių savaičių laikotarpiu [12 -14]. Mums nepavyko ilgesnị laiką stebèti odos pokyčiu, nes tiriamieji buvo išrašyti ar perkelti ị kitas įstaigas. M. Primiano ir kiti tyrèjai nustatè, kad pacientų gydymo laikotarpis, pratęstas vidutiniškai iki 11 dienų, padidina slaugos paslaugų apimtị net 25 procentais [14]. Kaip parode mūsų tyrimo duomenys, net 14 ir daugiau surinktų taškų skaičius negarantuoja odos pažeidimų išvengimą, jei nebus skatinamas tiriamujų mobilumas.

\section{Išvados}

1. Mažiau nei pusè tiriamųų, dažniau 55-74 metų, atvykimo metu turèjo slègio opų.

2. Daugiau nei pusę odos ir audinių vientisumo pažeidimo atvejų pastebèjo ir ịvertino slaugos personalas, dažniau tiriamiesiems iki 80 metų, atvykusiems gydytis planine tvarka. Labai didelę slègio opų atsiradimo tikimybę turèjo atvykusieji skubos tvarka, kurių odos būkle įvertinta 6-10 taškų ir ketvirtadalis atvykusių planine tvarka, kurių odos būklè įvertinta penkiais taškais. Ir moterų, ir vyrų slègio opu išsivystymo galimybès buvo vienodos.

3. Odos ir audinių vientisumo pažeidimams įtakos turi rizikos veiksniai: šlapinimosi, tuštinimosi problemos, psichologinè, odos būklè. Atvykimo ir odos pažeidimų gydymo metu, II stadijos slègio opų dažnumas vienodas. Daugiau nei pusei tiriamujų slègio opos lokalizacijos vieta buvo nugaros sritis, rečiau - kūno šonai, o gydymosi laikotarpiu - pilvo sritis. Tiriamiesiems, ịvertinus jų odos būklę mažiau nei 14 taškų ir turintiems slègio opų, taikytos profilaktinès ir slaugos pagalbinès priemonés slègio opų prevencijai.

\section{Literatūra}

1. Doughty D. Differential assessment of trunk wounds: pressure ulceration versus incontinence associated dermatitis versus intertriginous dermatitis. Ostomy Wound Man 2012;58(4):20-22.

2. Meesterberends E, et al. Pressure ulcer incidence in Dutch and German nursing homes: design of a prospective multicenter cohort study. BMC Nurs 2011;10: 8 .

https://doi.org/10.1186/1472-6955-10-8

3. Beeckman D, et al. A systematic review and metaanalysis of incontinence associated dermatitis, incontinence, and moisture as risk factors for pressure ulcer development. Res Nurs Health 2014;37(3):204-218.

https://doi.org/10.1002/nur.21593

4. Vanderwee K, et al. Pressure ulcer prevalence in Europe: a pilot study. J Eval Clin Pract 2007;13(2):227-235.

https://doi.org/10.1111/j.1365-2753.2006.00684.x

5. Denny K, et al. Compromised wounds in Canada. Healthcare Quarterly 2014;17(1):7-10.

https://doi.org/10.12927/hcq.2014.23787

6. Pečeliūnienė R. Tinkamai parinktos priemonès - slaugomų pacientų kokybiško gyvenimo garantas. Lietuvos gydytojų žurnalas, 2012;43(9):17.

7. Gunningberg L, Stotts N A. Tracking quality over time: what do pressure ulcer data show? Int J Qual Health Care 2008; 20(4):246-253.

https://doi.org/10.1093/intqhe/mzn009

8. Baharestani MM, et al. Dilemmas in measuring and using pressure ulcer prevalence and incidence: an international consensus. Int Wound J 2009;6(2):97-104. https://doi.org/10.1111/j.1742-481X.2009.00593.x

9. Gunningberg L, Brudin L, Idvall E. Nurse managers' prerequisite for nursing development: a survey on pressure ulcers and contextual factors in hospital organizations. J Nurs Manag 2010; 18(6):757-766.

https://doi.org/10.1111/j.1365-2834.2010.01149.x

10. Hill-Brown S. Reduction of pressure ulcer incidence in the home healthcare setting: a pressure relief seating cushion project to reduce the number of community acquired pressure ulcers. Home Healthc Nurse 2011;29(9):575-579.

https://doi.org/10.1097/NHH.0b013e31822eb830

11. Moore ZE, Webster J, Samuriwo R. Wound care teams for preventing and treating pressure ulcers. Cochrane Database Syst Rev, 2015;9:CD011011.

https://doi.org/10.1002/14651858.CD011011.pub2

12. Dumville JC, et al. Alginate dressings for treating pressure ulcers. Sao Paulo Med J 2015; 33(5):455.

https://doi.org/10.1590/1516-3180.20151335T2

13. Baterman Sh. Preventing pressure ulceration in surgical patients. Wounds UK 2012;4(8):65-73.

14. Primiano M, Friend M, McClure C, Nardi S, Fix L, Schfer M, et al. Pressure ulcer prevalence and risk factors during prolonged surgical procedures. AORN J 2011; 6(94):555-566.

https://doi.org/10.1016/j.aorn.2011.03.014

\section{IMPACT OF RISK FACTORS ON INJURIES OF SKIN AND TISSUE INTEGRITY}

Z. Gierasimovič, Z. Kuzborska, J. Kutkauskienė

Keywords: nursing care of pressure sores, external, internal factors, preventive measures. 
Summary

Work objective. To establish the factors which have an impact on the development of pressure sores.

Research material and method. The research was carried out at one of the University hospitals in the city of Vilnius. Risk of the development of pressure sores was assessed using the modified Norton scale. Cases of the development of pressure sores in 655 patients were analyzed.

Results and conclusions. Fewer than half the patients (41.5 per cent) and more frequently patients belonging to the age group between 55 and 74 years arrived for treatment having pressure sores already. The nursing staff noticed and assessed injuries of skin and tissue integrity in more than half of the cases (83.4 per cent), more frequently in the patients under the age of 80 who arrived to undergo planned treatment. Patients who were assessed at 6-10 points had a very high probability ( 2.6 per cent) of developing pressure sores upon arriving for urgent treatment and one fourth $(25.0$ per cent) of the patients who were assessed at 5 points and arrived for planned treatment. Both males and females had equal possibili- ties for the development of pressure sores $(\mathrm{p}=0.001)$. The following risk factors have an impact on injuries of skin and tissue integrity: skin condition (4.9 per cent), the psychological state (13.4 per cent), and urination (69.6 per cent). Pressure sores of stage II were equally often diagnosed in patients who arrived for treatment and who were undergoing treatment (55.6 per cent). The dorsal area is the place of localisation of pressure sores in more than half of the patients ( 60.0 per cent). The least probability to diagnose the place of localisation of pressure sores in the patients who arrived for treatment (1.2 percent) is the sides of the body and in the patients who are undergoing treatment ( 1.7 percent) pressure sores are localised in the area of the abdomen $(p=0.0001)$. Preventive and ancillary nursing measures were applied to the patients undergoing treatment with pressure sores ( 41.8 per cent).

Correspondence to: zitagieras@gmail.com

2020-01-23 